\title{
The Therapeutic Role of C-peptide in the Amelioration of Type 1 Diabetes Associated Microvascular Dysfunction of the Kidneys and Nerves
}

\author{
Gary Adams ${ }^{1 *}$, Susannah Champion², Gemma Figg ${ }^{2}$ and Alex Jervis ${ }^{2}$
}

${ }^{1}$ Insulin Diabetes Experimental Research Group, The University of Nottingham, UK

${ }^{2}$ School of Health Sciences, The University of Nottingham, UK

\begin{abstract}
Proinsulin C-peptide is biologically active and exerts a protective physiological role in Type 1 Diabetes mellitus. We evaluated the effect of C-peptide replacement on the renal and nerve function of patients with T1DM and attempted to determine the mechanism by which it may exert its effects. An electronic search for randomised control trials was carried out in the following databases; Pubmed, EMBASE, Medline, CINAHL, CENTRAL and Proquest. The primary results from included trials were statistically combined in a meta-analysis. Six (6) randomised control trials met the inclusion criteria. Two (2) investigated the effects of C-peptide on kidney function. Three (3) investigated the effects of C-peptide on nerve function. One (1) randomised control trial investigated the effect of C-peptide on both kidney and nerve function. C-peptide was found to exert statistically significant beneficial effects upon urinary albumin excretion, glomerular filtration rate and autonomic and sensory nerve function. When the results from these trials were combined in a meta-analysis, C-peptide was found to exert statistically significant beneficial effects upon albumin excretion and autonomic nerve function when compared to placebo. There is increasing evidence that C-peptide ameliorates the type 1 diabetes associated microvascular dysfunction seen in the kidneys and nerves. The mechanism of Cpeptides action appears to be complex and multifaceted and is not fully understood. Evidence from cell systems and experimental models of diabetes suggests that Cpeptide may influence $\mathrm{Na}^{+} \mathrm{K}^{+}$-ATPase and endothelial nitric oxide synthase activity in order to exert its beneficial effects.
\end{abstract}

Keywords: Therapeutic C-peptide; Type 1 diabetes; Microvascular dysfunction; Nephropathy; Neuropathy

\section{Introduction}

Glycaemic levels are controlled via a range of complex metabolic pathways, where insulin, a potent hypoglycaemic agent, is vital in order for plasma glucose levels to be maintained within the normal range of 4-7 mmol/L [1]. In Diabetes Mellitus (DM), a chronic metabolic condition characterised by chronic hyperglycaemia, glycaemic control is severely impaired as a result of a deficit in insulin or its action [2]. This deficit induces metabolic and degenerative microvascular and macrovascular complications in multiple organs including the heart, nerves, eyes and kidneys [3].

Biosynthesis of insulin occurs in the $\beta$-cells of the pancreas and involves a precursor molecule named Preproinsulin, a 110 amino acid peptide produced following the transcription and translation of the insulin gene. This peptide contains a lipophillic signalling peptide cleaved in the formation of Proinsulin [4]. Proinsulin consists of a carboxy-terminal A chain, an amino-terminal B chain and a 31 amino acid connecting peptide known as C-peptide [5]. During insulin synthesis, C-peptide is enzymatically cleaved from the molecule by endopeptidases and released into the blood stream in equimolar concentrations to insulin [6]. Unlike insulin, C-peptide is subject to a negligible first pass metabolism making it an ideal marker of residual $\beta$-cell function and consequently insulin secretion [7]. Several attempts were made to ascertain a physiological role for C-peptide. These attempts were unsuccessful and studies concluded that C-peptide was biologically inert with a role of merely serving as a link between the A and $\mathrm{B}$ chains of insulin ensuring correct folding and disulphide bond formation [8]. These assumptions were strengthened by the knowledge that the C-peptide molecule had shown profound structural variability and a lack of sequence conservation between species [9].

However, recent studies have suggested an active and protective physiological role for C-peptide, indicating that it may slow the progression of the microvascular complications seen in T1DM, including diabetic nephropathy and neuropathy.

For example, it is purported that C-peptide in the physiological concentrations has anti-inflammatory, immunomodulatory and neuroprotective effects, so that it and its synthetic analogues can be widely used to treat diabetes patients and to prevent complications, therein. To establish the clinically effective use of C-peptide in medicine, it is imperative that the molecular mechanisms of regulatory action of C-peptide on the fundamental cellular processes are studied in depth. C-peptide coupled with Gi/o protein-coupled receptors of the serpentine type regulates the functional activity of many intracellular signaling pathways, which include phospholipase $\mathrm{C}$ beta, different forms of protein kinase $\mathrm{C}$, phosphatidylinositol 3-kinases and mitogenactivated protein kinases, endothelial NO-synthase, $\mathrm{Na}+\mathrm{K}+$-ATPase, a wide range of transcription factors and nuclear receptors. In addition, C-peptide is said to control the stability of the insulin hexamer, and, thus, effects insulin-regulated signalling pathways [10-14].

Although it acknowledged that the structural variation of the peptide is considerable, in comparison to other active peptides this variability is not exceptional [8].

*Corresponding author: Gary Adams, Insulin Diabetes Experimental Research Group, Faculty of Medicine and Health Sciences, The University of Nottingham Nottingham, NG7 2UH, United Kingdom, Tel: +44(0)115-8230901; Fax: +44(0)1158230999; E-mail: Gary.Adams@nottingham.ac.uk

Received April 16, 2013; Accepted May 30, 2013; Published June 05, 2013

Citation: Adams G, Champion S, Figg G, Jervis A (2013) The Therapeutic Role of C-peptide in the Amelioration of Type 1 Diabetes Associated Microvascula Dysfunction of the Kidneys and Nerves. J Diabetes Metab 4: 267. doi:10.4172/2155 6156.1000267

Copyright: ( 2013 Adams G, et al. This is an open-access article distributed unde the terms of the Creative Commons Attribution License, which permits unrestricted use, distribution, and reproduction in any medium, provided the original author and source are credited. 


\section{Therapeutic Role of C-Peptide in Type 1 Diabetes Associated Microvascular Dysfunction of the Kidneys and Nerves}

\section{Search strategy - data sources}

EMBASE; PubMed; MEDLINE; CINAHL and The Cochrane Central Register of Controlled trials (CENTRAL) which includes details of published and unpublished sources and Proquest were systematically searched from 1992-2012. An initial basic search using the search terms identified 188,346 results. The search process was subsequently refined in an advanced search using Boolean phrasing techniques and the implementation of date limits. The refined search retrieved a total of 1536 results.

Studies were included in this review if they: 1) utilised RCT methodology, 2) used participants who had T1DM, 3) gave C-peptide as the therapeutic intervention, 4) reported outcome measures as measures of renal or nerve function. Outcome measures in eligible studies therefore included GFR, albumin excretion rate (AER), effective renal plasma flow (ERPF), filtration fraction (FF) and NCV, vibration perception thresholds (VPT), heat and cold perception thresholds and heart rate variability (HRV) respectively.

The titles of all 1536 retrieved articles were screened and examined for potential inclusion into the review. If deemed irrelevant or if they explicitly did not meet the inclusion criteria they were excluded at this stage. The abstracts of the remaining articles were then screened according to the inclusion and exclusion criteria. The articles identified during the study selection process were assessed for eligibility for inclusion using the above criteria.

A critical appraisal skills programme (CASP) toolkit for RCTs was used as a framework for critical appraisal (Public Health Resource Unit (PHRU), 2006). The risk of bias was assessed using the recommended Cochrane Collaboration tool for assessing the risk of bias. The following information was extracted from each RCT and documented on a data extraction form: author, year published, country of origin, aims and objectives, study design, inclusion and exclusion criteria, baseline characteristics (age, duration of diabetes, severity of microvascular complications), number of participants in each study group, description of intervention (dosage, route of administration, duration of intervention), outcome data and methodological quality.

\section{Meta-analysis}

The degree of heterogeneity was assessed and identified for each outcome using Review Manager (RevMan) software (Cochrane, Version 5.1) and presented as a percentage value $\left(\mathrm{I}^{2}\right)$; the higher the $\mathrm{I}^{2}$ percentage, the higher the heterogeneity and the higher the possibility of producing misleading conclusions. Using RevMan software, one pair-wise comparison was evaluated in this meta-analysis; C-peptide vs. Placebo. Within this comparison, the summary statistics reported in the included primary studies were statistically combined for the following outcomes; GFR, urinary albumin excretion, SCV, MCV, VPT, thermal thresholds and HRV. For comparison of studies using different measurement scales, standardised mean difference was used as the effect measure. In contrast, mean differences were used as the intervention effect measures for those outcomes which utilised the same measurement scale. 95\% confidence intervals were used ( $P$ value $<0.05)$. A random-effects meta-analysis was utilised due to the fact that this method assumes that the studies are estimating different, yet related, intervention effects.

\section{Results and Discussion}

Our literature search produced 1536 citations, of which we selected 6 for further review of the full text (Figure. 1). 1,530 studies were excluded for reasons listed in figure 1. Therefore, six publications met our criteria for inclusion in this review and meta-analysis.

\section{The effect of C-peptide on kidney function}

Johansson et al., 1992 (Study 1) monitored the renal function of eleven T1DM patients during a 120 minute intravenous infusion of C-peptide [15]. Results were compared to a control group of ten patients with T1DM receiving $0.9 \%$ saline over the same time period. No adverse reactions occurred during. The study was discontinued in four patients after an hour due to difficulties voiding in the supine position. As a result, only seven participants received the high dose C-peptide intervention (Table 1).

A statistically significant reduction $(p<0.001)$ in GFR was found during the low dose C-peptide infusion [16]. In the C-peptide group the average GFR of the eleven participants was $143 \pm 3 \mathrm{ml}^{-m^{-1}} \cdot 1.73$ $\mathrm{m}^{-2}$ at baseline. After a 60 minute infusion of low dose C-peptide the average GFR reduced to $133 \pm 4 \mathrm{ml} \mathrm{min}^{-1} \cdot 1.73 \mathrm{~m}^{-2}$. This reduction amounted to approximately $7 \%$ and a reduction in GFR was found in each of the eleven patients studied. The seven participants who went on to receive a 60 minute infusion of high dose C-peptide saw a further decline in GFR, though not statistically significant $\left(136 \pm 4 \mathrm{ml} \mathrm{min}^{-1}\right.$ $1.73 \mathrm{~m}^{-2}$ to $132 \pm 4 \mathrm{ml} \cdot \mathrm{min}^{-1} \cdot 1.73 \mathrm{~m}^{-2}, \mathrm{P}<0.1$ ). No statistically significant changes in GFR were found in the control group after a sixty minute infusion of normal saline. When comparing the intervention group with the control group, the reduction in GFR from baseline to low dose $\mathrm{C}$-peptide and from baseline to high dose C-peptide was greater than the corresponding periods in the placebo group $(\mathrm{p}<0.001$ and $\mathrm{p}<0.05$ respectively). Furthermore, the four individuals, who participated in both the C-peptide and placebo group showed a more marked reduction in GFR when they received $\mathrm{C}$-peptide for 60 minutes $(\mathrm{P}<0.05)$.

ERPF increased slightly from the basal state during the low dose $\mathrm{C}$-peptide infusion. At baseline the ERPF in the group receiving C-peptide was $741 \pm 34 \mathrm{mlmin}^{-1} \cdot 1.73 \mathrm{~m}^{-2}$. At the end of the low dose C-peptide infusion this increased by approximately $3 \%$ to $760 \pm 35$ $\mathrm{mlmin}^{-1} \cdot 1.73 \mathrm{~m}^{-2}(\mathrm{P}<0.05)$. By the end of the high dose infusion, ERPF had risen by $6 \%$ in relation to the basal value $(\mathrm{p}<0.05)$. No significant changes were found in the control subjects. Although both groups saw a reduction in FF, the ratio between GFR and ERPF, after 60 minutes and

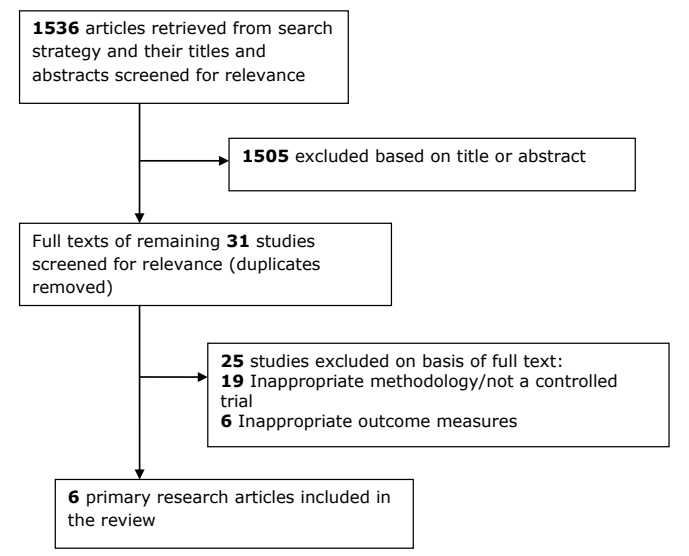

Figure 1: Search results and details of exclusion process. 
Citation: Adams G, Champion S, Figg G, Jervis A (2013) The Therapeutic Role of C-peptide in the Amelioration of Type 1 Diabetes Associated Microvascular Dysfunction of the Kidneys and Nerves. J Diabetes Metab 4: 267. doi:10.4172/2155-6156.1000267

Page 3 of 10

\begin{tabular}{|c|c|c|c|c|c|c|c|c|}
\hline Authors & Date & Country & Study Design & Statistical technique & Outcome & Intervention Group (IG) & Control Group (CG) & $\begin{array}{c}\text { Methodological } \\
\text { Quality }\end{array}$ \\
\hline \multirow[t]{4}{*}{$\begin{array}{l}\text { Johansson, } \\
\text { BL, Sjoberg S, } \\
\text { Wahren J } \\
\text { (Study 1) }\end{array}$} & \multirow[t]{4}{*}{1992} & \multirow[t]{4}{*}{ Sweden } & \multirow[t]{4}{*}{ Controlled Trial } & \multirow[t]{4}{*}{$\begin{array}{l}\text { Paired t-test, } \\
\text { Wilcoxon's signed } \\
\text { rank test and } \\
\text { analyses of variance. }\end{array}$} & GFR & $\begin{array}{l}\text { Basal }(n=11): 143 \pm 4 \\
\text { Low-dose }(n=11): 133 \pm 4 \\
\text { High-dose }(n=7): 132 \pm 4\end{array}$ & $\begin{array}{l}\text { Basal }(n=10): 132 \pm 4 \\
60 \min (n=10): 130 \pm 4 \\
120 \min (n=10): 127 \pm 3\end{array}$ & 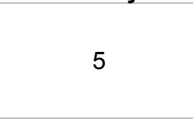 \\
\hline & & & & & ERPF & $\begin{array}{l}\text { IG } \\
\text { Basal }(n=11): 741 \pm 34 \\
\text { Low-dose }(n=11): 760 \pm 35 \\
\text { High-dose }(n=7): 791 \pm 34\end{array}$ & $\begin{array}{l}\text { CG } \\
\text { Basal }(n=10): 708 \pm 22 \\
60 \min (n=10): 728 \pm 23 \\
120 \min (n=10): 725 \pm 28\end{array}$ & \\
\hline & & & & & FF & $\begin{array}{l}\text { Basal }(n=11): 19.3 \pm 0.5 \\
\text { Low-dose }(n=11): 17.6 \pm 0.5 \\
\text { High-dose }(n=7): 16.8 \pm 0.3\end{array}$ & $\begin{array}{l}\text { Basal }(n=10): 18.8 \pm 0.7 \\
60 \min (n=10): 17.9 \pm .6 \\
120 \min (n=10): 17.2 \pm 0.7\end{array}$ & \\
\hline & & & & & $\begin{array}{l}\text { PAH } \\
\text { extraction }\end{array}$ & $\begin{array}{l}\text { Basal }(n=11): 90 \pm 1 \\
\text { Low-dose }(n=11): 92 \pm 2 \\
\text { High-dose }(n=7): 91 \pm 3\end{array}$ & $\begin{array}{l}\text { Basal }(n=10): 90 \pm 1 \\
60 \min (n=10): 90 \pm 1 \\
120 \min (n=10): 91 \pm 1\end{array}$ & \\
\hline \multirow[t]{4}{*}{$\begin{array}{l}\text { Johansson, BL, } \\
\text { Kernell A, Sjoberg } \\
\text { S, Wahren J } \\
\text { (Study 2) }\end{array}$} & \multirow[t]{4}{*}{1993} & \multirow[t]{4}{*}{ Sweden } & \multirow[t]{4}{*}{$\begin{array}{l}\text { Double-blind, } \\
\text { randomised } \\
\text { control trial }\end{array}$} & \multirow[t]{4}{*}{$\begin{array}{l}\text { Student's t test and } \\
\text { Wilcoxon's sign rank } \\
\text { test. }\end{array}$} & GFR & $\begin{array}{l}\text { Basal: } 147 \pm 5 \\
2 \text { weeks: } 138 \pm 6 \\
4 \text { weeks: } 138 \pm 6\end{array}$ & $\begin{array}{l}\text { Basal: } 142 \pm 6 \\
2 \text { weeks: } 141 \pm 6 \\
4 \text { Weeks: } 142 \pm 5\end{array}$ & 6 \\
\hline & & & & & ERPF & $\begin{array}{l}\text { Basal: } 734 \pm 65 \\
2 \text { weeks: } 715 \pm 53 \\
4 \text { weeks: } 663 \pm 29\end{array}$ & $\begin{array}{l}\text { Basal: } 634 \pm 47 \\
2 \text { weeks: } 575 \pm 77 \\
4 \text { weeks: } 611 \pm 44\end{array}$ & \\
\hline & & & & & FF & $\begin{array}{l}\text { Basal: } 21 \pm 2 \\
2 \text { weeks: } 20 \pm 2 \\
4 \text { weeks: } 21 \pm 1\end{array}$ & $\begin{array}{l}\text { Basal: } 23 \pm 1 \\
2 \text { weeks: } 27 \pm 3 \\
4 \text { weeks: } 24 \pm 2\end{array}$ & \\
\hline & & & & & UAE & $\begin{array}{l}\text { Basal: } 21 \pm 6 \\
2 \text { weeks: } 12 \pm 2 \\
4 \text { weeks: } 9 \pm 1\end{array}$ & $\begin{array}{l}\text { Data not given but states } \\
\text { unchanged }\end{array}$ & \\
\hline \multirow{6}{*}{$\begin{array}{l}\text { Johansson } \\
\text { BL, Borg K, } \\
\text { Fernqvist-Forbes } \\
\text { E, Odergren } \\
\text { T, Remahl S, } \\
\text { Wahren J_- } \\
\text { (Study 3) }\end{array}$} & \multirow{6}{*}{1996} & \multirow{6}{*}{ Sweden } & \multirow{6}{*}{$\begin{array}{l}\text { Double-blind, } \\
\text { randomised, } \\
\text { cross-over, } \\
\text { controlled trial }\end{array}$} & \multirow{6}{*}{$\begin{array}{l}\text { As means } \pm \\
\text { SEM. Statistical } \\
\text { tests:student's t } \\
\text { test, signed rank } \\
\text { test, Wilcoxon's } \\
\text { sum rank test } \\
\text { Wilcoxon's matched } \\
\text { pairs. P values } \\
<0.05 \text { statistically } \\
\text { significant. }\end{array}$} & $\begin{array}{l}\text { Change in } \\
\text { vibratory } \\
\text { threshold }\end{array}$ & $(n=8): 2 \pm 11$ & $(n=8):-4 \pm 8$ & \multirow{6}{*}{6} \\
\hline & & & & & $\begin{array}{l}\text { Heart rate } \\
\text { variability }\end{array}$ & $\begin{array}{l}\text { Basal }(n=11): 13 \pm 1 \\
\text { During infusion }(n=11): 20 \\
\pm 2\end{array}$ & $\begin{array}{l}\text { Basal }(n=11): 14 \pm 2 \\
\text { During infusion }(n=11) \text { : } \\
15 \pm 2\end{array}$ & \\
\hline & & & & & $\begin{array}{l}\text { Brake Index } \\
\text { during tilting }\end{array}$ & $\begin{array}{l}\text { Basal }(n=7): 4.6 \pm 1.0 \\
\text { Infusion: } 10.3 \pm 2.2\end{array}$ & $\begin{array}{l}\text { Basal }(n=7): 5.9 \pm 2.5 \\
\text { Infusion: } 4.1 \pm 1.1\end{array}$ & \\
\hline & & & & & $\begin{array}{l}\text { Acceleration } \\
\text { Index during } \\
\text { tilting }\end{array}$ & $\begin{array}{l}\text { Basal }(n=4): 8.2 \pm 0.9 \\
\text { Infusion: } 14.5 \pm 4.8\end{array}$ & $\begin{array}{l}\text { Basal }(n=4): 8.5 \pm 2.5 \\
\text { Infusion: } 9.3 \pm 1.9\end{array}$ & \\
\hline & & & & & $\begin{array}{l}\text { Warm-cold } \\
\text { difference }\end{array}$ & $(n=8): 9 \pm 6$ & $(n=8):-2 \pm 4$ & \\
\hline & & & & & $\begin{array}{l}\text { Heat pain } \\
\text { threshold }\end{array}$ & $(n=8): 1 \pm 1$ & $(n=8): 0 \pm 1$ & \\
\hline \multirow[t]{6}{*}{$\begin{array}{l}\text { Johansson BL, } \\
\text { Borg K, Fernqvist- } \\
\text { Forbes E, Kernell } \\
\text { A, Odergren T, } \\
\text { Wahren, J } \\
\text { (Study 4) }\end{array}$} & \multirow[t]{6}{*}{2000} & Sweden & $\begin{array}{l}\text { Double-blind, } \\
\text { randomised, } \\
\text { multi-centre, } \\
\text { cross-over, } \\
\text { controlled trial }\end{array}$ & $\begin{array}{l}\text { As means } \pm \text { SEM. } \\
\text { Geometric means } \\
\text { used for UAE and } \\
\text { albumin/ } \\
\text { creatinine excretion. } \\
\text { Student's t test and } \\
\text { Wilcoxon's matched- } \\
\text { pair test used to } \\
\text { evaluate autonomic } \\
\text { and sensory nerve } \\
\text { function. }\end{array}$ & AER & $\begin{array}{l}\text { GROUP } 1(n=10) \\
\text { Baseline: } 56 \\
1 \text { month: } 46 \\
2 \text { month: } 47 \\
3 \text { month: } 37 \\
\text { GROUP } 2 \\
\text { (n=11) } \\
4 \text { month: } 54 \\
5 \text { month: } 36\end{array}$ & $\begin{array}{l}\text { GROUP } 1(n=10) \\
4 \text { month: } 46 \\
5 \text { month: } 46 \\
6 \text { month: } 51 \\
\\
\text { GROUP } 2 \\
\text { (n=11) } \\
\text { Baseline: } 49 \\
1 \text { month: } 49 \\
2 \text { month: } 53 \\
3 \text { month: } 60\end{array}$ & 6 \\
\hline & & & & & GFR & $\begin{array}{l}\text { GROUP } 1 \\
\text { Baseline: } \\
106 \pm 6 \\
\text { Month 3: } 105 \pm 5 \\
\text { GROUP 2 } \\
\text { Month 6: } 108 \pm 3\end{array}$ & $\begin{array}{l}\text { GROUP } 1 \\
\text { Month 6: } 101 \pm 6 \\
\text { GROUP 2 } \\
\text { Baseline: } 111 \pm 3 \\
\text { Month 3: } 111 \pm 5\end{array}$ & \\
\hline & & & & & $\begin{array}{l}\text { Heart rate } \\
\text { variability }\end{array}$ & $\begin{array}{l}(\mathrm{n}=12) \\
\text { Baseline: } 18 \pm 2 \\
\text { After C-peptide: } 21 \pm 1\end{array}$ & $\begin{array}{l}(n=12) \\
\text { Baseline: } \\
19 \pm 1 \\
\text { After placebo: } 16 \pm 1\end{array}$ & \\
\hline & & & & & $\begin{array}{l}\text { Vibratory } \\
\text { Threshold }\end{array}$ & $\begin{array}{l}(\mathrm{n}=6) \\
\text { Baseline: } 7.0 \pm 2.3 \\
\text { 3/12 C-peptide: } 9.4 \pm 3.0\end{array}$ & $\begin{array}{l}(n=6) \\
\text { Baseline: } 7.9 \pm 3.0 \\
\text { 3/12 placebo: } 7.5 \pm 2.2\end{array}$ & \\
\hline & & & & & $\begin{array}{l}\text { Heat-pain } \\
\text { threshold }\end{array}$ & $\begin{array}{l}(n=6) \\
\text { Baseline: } 47.6 \pm 0.8 \\
\text { 3/12 C-peptide: } 49.9 \pm 1.3\end{array}$ & $\begin{array}{l}(n=6) \\
\text { Baseline: } 48.1 \pm 0.8 \\
\text { 3/12 placebo: } 48.0 \pm 0.6\end{array}$ & \\
\hline & & & & & $\begin{array}{l}\text { Brake and } \\
\text { acceleration } \\
\text { indices }\end{array}$ & $\begin{array}{l}\text { Break indices tended to } \\
\text { improve with C-peptide } \\
(P<0.1) \text {. The acceleration } \\
\text { index improved in one of the } \\
\text { two patients. }\end{array}$ & $\begin{array}{l}\text { Both indices were } \\
\text { unchanged during placebo } \\
\text { treatment }\end{array}$ & \\
\hline
\end{tabular}


Citation: Adams G, Champion S, Figg G, Jervis A (2013) The Therapeutic Role of C-peptide in the Amelioration of Type 1 Diabetes Associated Microvascular Dysfunction of the Kidneys and Nerves. J Diabetes Metab 4: 267. doi:10.4172/2155-6156.1000267

Page 4 of 10

\begin{tabular}{|c|c|c|c|c|c|c|c|c|}
\hline & & & & & $\begin{array}{l}\text { Postural } \\
\text { hypotension }\end{array}$ & $\begin{array}{l}\text { Both patients with postural } \\
\text { hypotension prior to the } \\
\text { study beginning tolerated } \\
\text { the } 8 \text { minute tilting well with } \\
\text { normal BP responses after } \\
\text { C-peptide treatment. }\end{array}$ & $\begin{array}{l}\text { The same two patients } \\
\text { became symptomatically } \\
\text { hypotensive during } \\
\text { tilting after } 3 / 12 \text { placebo } \\
\text { treatment. }\end{array}$ & \\
\hline \multirow[t]{8}{*}{$\begin{array}{l}\text { Ekberg K, Brismar } \\
\text { T, Johansson } \\
\text { B/L/. Jonsson } \\
\text { B, Lindstrom P, } \\
\text { Wahren J (Study } \\
\text { 5) }\end{array}$} & 2003 & Sweden & $\begin{array}{l}\text { Randomised, } \\
\text { double blind, } \\
\text { placebo } \\
\text { controlled }\end{array}$ & $\begin{array}{l}\text { As mean } \pm \text { SEM. } \\
\text { Mann Whitney } \\
\text { two to undertake } \\
\text { comparison between } \\
\text { groups. Wilcoxon's } \\
\text { signed rank test to } \\
\text { compare between } \\
\text { groups. }\end{array}$ & & & & 8 \\
\hline & & & & & MCV & $\begin{array}{l}\text { (Baseline } 44.9 \pm 0.79) \\
6 \text { weeks: } 0.8 \pm 0.32 \\
12 \text { weeks: } 0.1 \pm 0.29\end{array}$ & $\begin{array}{l}\text { (Baseline: } 67.7 \pm 0.71 \text { ) } \\
6 \text { weeks: } 0.3 \pm 0.41 \\
12 \text { weeks: }-0.7 \pm 0.39\end{array}$ & \\
\hline & & & & & CMAP & $\begin{array}{l}\text { (Baseline: } 6.96 \pm 0.50) \\
6 \text { weeks: } 0.4 \pm 0.36 \\
12 \text { weeks: } 0.1 \pm 0.29\end{array}$ & $\begin{array}{l}\text { (Baseline: } 7.60 \pm 0.41 \text { ) } \\
6 \text { weeks: } 0.4 \pm 0.27 \\
12 \text { weeks: } 0.2 \pm 0.29\end{array}$ & \\
\hline & & & & & SCV & $\begin{array}{l}\text { Baseline: }(50.5 \pm 0.89) \\
6 \text { weeks: } 1.6 \pm 0.76 \\
12 \text { weeks: } 2.7 \pm 0.85\end{array}$ & $\begin{array}{l}\text { Baseline: }(51.4 \pm 1.12) \\
6 \text { weeks: } 0.6 \pm 0.91 \\
12 \text { weeks: } 0.6 \pm 0.80\end{array}$ & \\
\hline & & & & & SNAP & $\begin{array}{l}\text { (Baseline: } 16.3 \pm 1.81 \text { ) } \\
6 \text { weeks: } 0.6 \pm 1.10 \\
12 \text { weeks: } 0.7 \pm 1.19\end{array}$ & $\begin{array}{l}\text { (Baseline: } 15.8 \pm 1.92 \text { ) } \\
6 \text { weeks: } 0.9 \pm 0.95 \\
12 \text { weeks: } 3.4 \pm 0.98\end{array}$ & \\
\hline & & & & & $\begin{array}{l}\text { Cold } \\
\text { threshold }\end{array}$ & $\begin{array}{l}\text { (Baseline: } 3.4 \pm 0.55 \text { ) } \\
12 \text { weeks:0.3 } \pm 0.46\end{array}$ & $\begin{array}{l}\text { (Baseline: } 2.1 \pm 0.17 \text { ) } \\
12 \text { weeks: } 0.2 \pm 0.2\end{array}$ & \\
\hline & & & & & $\begin{array}{l}\text { Heat } \\
\text { threshold }\end{array}$ & $\begin{array}{l}\text { Baseline: } 8.0 \pm 0.43 \\
12 \text { weeks: } 0.3 \pm 0.31\end{array}$ & $\begin{array}{l}\text { Baseline: } 7.0 \pm 0.47 \\
12 \text { weeks: } 0.1 \pm 0.26\end{array}$ & \\
\hline & & & & & $\begin{array}{l}\text { Vibration } \\
\text { threshold }\end{array}$ & $\begin{array}{l}\text { Baseline: } 0.63 \pm 0.07 \\
12 \text { weeks: }-0.2 \pm 0.07\end{array}$ & $\begin{array}{l}\text { Baseline: } 0.48 \pm 0.07 \\
12 \text { weeks: } 0 \pm 0.06\end{array}$ & \\
\hline \multirow[t]{6}{*}{$\begin{array}{l}\text { Ekberg K, Brismar } \\
\text { T, Johansson } \\
\text { BL, Lindstrom P, } \\
\text { Juntti-Berggren } \\
\text { L, Norrby A, } \\
\text { Berne C, Arnqvist } \\
\text { HJ, Bolinder J, } \\
\text { Wahren J } \\
\text { (Study 6) }\end{array}$} & 2007 & Sweden & $\begin{array}{l}\text { Double-blind, } \\
\text { randomised, } \\
\text { placebo } \\
\text { controlled, } \\
\text { multi-centre }\end{array}$ & $\begin{array}{l}\text { As means } \pm \text { SEM. } \\
\text { Nerve conduction } \\
\text { data in z-scores. QST } \\
\text { as z-scores corrected } \\
\text { for age. The Wilcoxon } \\
\text { signed-rank: } \\
\text { compare baseline } \\
\text { data and changes } \\
\text { between and within } \\
\text { groups. }\end{array}$ & & & & 8 \\
\hline & & & & & SCVp & $\begin{array}{l}\text { Baseline: } 35.4 \pm 0.31 \\
\text { Low dose }(n=53): 0.38 \pm \\
0.27 \\
\text { High dose }(n=30): \\
0.63 \pm 0.26 \\
\text { Active combined: } \\
0.48 \pm 0.19\end{array}$ & $\begin{array}{l}\text { Baseline: } 35.4 \pm 0.31 \\
\text { Placebo }(n+47): \\
0.24 \pm 0.27\end{array}$ & \\
\hline & & & & & SCVi & $\begin{array}{l}\text { Baseline: } 44.2 \pm 0.41 \\
\text { Low dose: } 0.77 \pm 0.43 \\
\text { High dose: } 1.14 \pm 0.36 \\
\text { Active combined: } 0.93 \pm \\
0.29\end{array}$ & $\begin{array}{l}\text { Baseline: } 44.2 \pm 0.41 \\
\text { Placebo: } 0.75 \pm 0.38\end{array}$ & \\
\hline & & & & & MCV & $\begin{array}{l}\text { Baseline: } 40.0 \pm 0.41 \\
\text { Low dose: }-0.25 \pm 0.19 \\
\text { High dose:-0.57 } \pm 0.24 \\
\text { Active combined: }-0.38 \pm \\
0.15\end{array}$ & $\begin{array}{l}\text { Baseline: } 40.0 \pm 0.41 \\
\text { Placebo: }-0.53 \pm 0.22\end{array}$ & \\
\hline & & & & & z-VPT foot & $\begin{array}{l}\text { Baseline: } 1.9 \pm 0.12 \\
\text { Low dose: }-0.07 \pm 0.09 \\
\text { High dose: }-0.12 \pm 0.11 \\
\text { Active combined: }-0.09 \pm \\
0.07\end{array}$ & $\begin{array}{l}\text { Baseline: } 1.9 \pm 0.12 \\
\text { Placebo: } 0.03 \pm 0.13\end{array}$ & \\
\hline & & & & & $\begin{array}{l}\text { z-VPT lower } \\
\text { leg }\end{array}$ & $\begin{array}{l}\text { Baseline: } 0.6 \pm 0.10 \\
\text { Low dose: }-0.07 \pm 0.09 \\
\text { High dose:-0.12 } \pm 0.11 \\
\text { Active combined: }-0.19 \pm \\
0.06\end{array}$ & $\begin{array}{l}\text { Baseline: } 0.6 \pm 0.10 \\
\text { Placebo:- } 0.09 \pm 0.08\end{array}$ & \\
\hline
\end{tabular}

Table 1: Study Characteristics.

120 minutes, the reduction in the C-peptide group was more marked during corresponding periods $(\mathrm{p}<0.01)$. These results are in line with those recently found where C-peptide ameliorates kidney injury [17].

Although this study showed promising findings, several limitations were identified upon completion of the quality assessment. No specific information was given regarding the randomisation or allocation process resulting in a high risk of selection bias. As a result it is impossible for the reviewer to know if there was a biased allocation to interventions which may subsequently impact on the validity of the results. Furthermore, four participants who participated in the control group had previously been studied in the C-peptide group. It 
is acknowledged that in cross-over trials participants received both the intervention and placebo and acted as own controls [18]. However, the study did not have a cross-over design and not all participants received both C-peptide and placebo. Furthermore, no explanation was given as to why this was done. Moreover, no attempt was made to analyse how participating in both groups of the study may have affected the results. In cross-over designs a washout period should be calculated to allow the effects of the previous treatment to disappear. In Study 1 (Johansson et al. 1992), the only information available was that the four participants had participated in the C-peptide infusion study three to twelve months before.

This study does not state that it was blinded which would usually introduce the risk of performance or observer bias. However, the outcomes used in this study such as GFR are unlikely to be altered as a result of participant knowledge of which group they are allocated to. Furthermore, the outcomes are measured using laboratory techniques rather than being based on clinical judgement. Finally, it should be noted that no power calculation was completed and the sample size was small therefore limiting the reliability and validity of the study's conclusions.

Following the previous findings, Johansson et al., 1993 (Study 2) investigated the effects of C-peptide on renal function over a longer experimental period [22]. They conducted a double-blind RCT which compared the renal function of nine T1DM patients receiving combined C-peptide and insulin therapy (group one) with nine similar patients who received insulin only for four weeks (group two). The mean GFR for group one was $147 \pm 5 \mathrm{ml} \cdot \mathrm{min}^{-1} \cdot 1.73 \mathrm{~m}^{-2}$ at baseline. After two weeks of C-peptide replacement the GFR had significantly reduced to $138 \pm 6$ $\mathrm{mlmin}^{-1} \cdot 1.73 \mathrm{~m}^{-2}(\mathrm{P}<0.05)$. No further decrease was seen after another two weeks of $\mathrm{C}$-peptide replacement. The reduction seen between baseline and two and four weeks of $\mathrm{C}$-peptide administration amounted to $6 \%$, a statistically significant difference $(\mathrm{P}<0.05)$. In contrast, in the control group, no statistically significant changes in GFR were observed (Table 1).

No statistically significant changes in ERPF were observed in both groups during the study. The FF, remained unchanged in group one throughout the study $\left(21 \pm 2 \mathrm{ml} / \mathrm{min} \cdot 1.73 \mathrm{~m}^{-1}, 20 \pm 2 \mathrm{ml} / \mathrm{min} \cdot 1.73\right.$ $\mathrm{m}^{-1}$ and $21 \pm 2 \mathrm{ml} / \mathrm{min} \cdot 1.73 \mathrm{~m}^{-1}$ at baseline, two weeks and four weeks respectively). In group two, the FF rose from $23 \pm 1 \mathrm{ml} / \mathrm{min} \cdot 1.73 \mathrm{~m}^{-2}$ at baseline to $27 \pm 3 \mathrm{ml} / \mathrm{min} \cdot 1.73 \mathrm{~m}^{-2}$ after two weeks post-treatment with placebo. Therefore, there was a statistically significant difference in FF between the two groups at two weeks of treatment. No further increase in $\mathrm{FF}$ was seen at four weeks.

Nevertheless, glomerular hyperfiltration is considered a potential therapeutic target in the prevention of diabetic nephropathy [19-21].

Johansson et al., 1993 also analysed urinary albumin excretion as an outcome measure. A gradual decrease in albumin excretion was found in the C-peptide treated group [22]. At baseline urinary albumin excretion was $21 \pm 6 \mu \mathrm{g}$. This reduced to $12 \pm 2$ and $9 \pm 1 \mu \mathrm{g} / \mathrm{min}$ at two and four weeks, respectively. It is reported that group two showed no change in albumin excretion at the corresponding times. Furthermore, the albumin excretion at four weeks was significantly lower in the C-peptide than the control group $(\mathrm{P}<0.05)$.

Despite Johansson et al., 1993 showing promising findings, several limitations were identified. The authors stated they employed a randomised, double-blind study design, although no further detail is given. Consequently, it is unclear whether or not the risks of selection, performance or detection bias were effectively minimised, limiting the internal validity of the study. Moreover, Johansson et al., 1993 study had a small sample size (eighteen participants) and no power calculation was reported. With only nine participants in each of the study groups the external validity of this remains unclear [23]. Although Study 2 (Johansson et al., 1993) had a longer experimental period than Study 1 (Johansson et al., 1992), four weeks is still considered a short duration.

The effects of C-peptide on urinary AER and GFR in a double-blind, randomised, cross-over design study over two three month periods was investigated by Johansson et al., 2000 (Study 4). During C-peptide treatment, the average AER decreased gradually from the baseline value of $58 \mu \mathrm{g} / \mathrm{min}$ to $34 \mu \mathrm{g} / \mathrm{min}$ after three months $(\mathrm{P}<0.01)$. In comparison, during the placebo period, the average AER tended to increase however this change was not significant. The difference observed between the two treatment periods was statistically significant $(\mathrm{P}<0.01)$.

Due to the nature of the cross-over study design, the possible presence of a sequence effect needed to be investigated. This was done by comparing the average slopes of regression for albumin excretion on time for patients receiving C-peptide during the first study period with those receiving C-peptide during the second study period. The same was completed for the placebo periods. No significant differences were found and as a result the findings from the two study periods were combined to produce the results. Regression analysis of the combined AER data during C-peptide administration showed a significant decrease in AER during the study period $(-0.18 \pm 0.06, \mathrm{P}<0.01)$. There was no significant change in AER during the placebo period. Furthermore, the regression coefficients of the C-peptide and placebo periods were found to be statistically different $(\mathrm{P}<0.01)$ indicating that the groups differed with regard to changes in AER during the study periods. Analysis of variance was completed in order to test for the difference between two or more means [24]. Overall, a 30\% reduction in AER (statistically significant $(\mathrm{P}<0.05)$ ) was found after 2 months C-peptide administration. The $40 \%$ decrease in AER at three months of C-peptide treatment was also considered statistically significant ( $\mathrm{P}$ $<0.01$ ). During the two study periods in Study 4 [12], no statistically significant changes in GFR were observed (Table 2).

\section{The effect of C-peptide on nerve function}

In 1996, Johansson et al. (Study 3) found evidence to suggest that a three hour infusion of C-peptide improves the autonomic nerve function of patients with T1DM [25], which is further supported by Galuska and colleagues [26]. At baseline, signs of parasympathetic neuropathy were present in eleven of the twelve patients studied as evidenced by a reduced E/I ratio during deep breathing. However, after a 180 minute C-peptide infusion, an increase was seen in the $\mathrm{E} / \mathrm{I}$ ratio of all eleven patients, five of which became completely normalised. An increase in HRV from baseline was seen during the C-peptide infusion (13 $\pm 1 \%$ and $20 \pm 2 \%$ at baseline and during C-peptide infusion, respectively). The HRV remained unchanged during the placebo period ( $14 \pm 2 \%$ and $15 \pm 2 \%$ at baseline and during placebo infusion, respectively). The average percentage improvement in respiratory HRV from baseline during $\mathrm{C}$-peptide was $63 \pm 6 \%(\mathrm{P}<0.001)$. In comparison, the improvement in the same outcome after placebo was only $14 \pm 6 \%$.

The brake index was found to be reduced in seven of the participants at baseline. During the C-peptide infusion a statistically significant increase was seen from $4.6 \pm 1 \%$ in the basal state to $10.3 \pm 2.2 \%$ after the intervention $(\mathrm{P}<0.05)$. No statistically significant change was seen during the placebo infusion ( $5.9 \pm 2.5 \%$ at baseline and $4.1 \pm 1.1 \%$ after saline) Four patients had a low acceleration index at baseline. Again, this was improved from an average of $8.2 \pm 0.9 \%$ at baseline to $14.5 \pm 4.8$ during the C-peptide infusion, however, a significant difference could not be found. 
No statistically different changes were found between the treatment groups on the two study occasions in the reactions of heart rate and blood pressure during the orthostatic testing [25]. However, one participant had a significant fall in systolic blood pressure from $135 \mathrm{mmHg}$ to $60 \mathrm{mmHg}$ after $4-6$ minutes of standing at baseline measurements and also during the placebo infusion. This participant also demonstrated an increase in heart rate from 90 to 130 beats per minute during the same time periods. As a result, the test had to be interrupted due to severe dizziness. However, during the C-peptide infusion the participant experienced no episodes of dizziness and was able to tolerate the upright position for 8 minutes. The blood pressure response to orthostatic testing during the C-peptide infusion was normal but an increase in heart rate from 60 to 115 beats per minute was still seen.

A neurophysical clinical examination was only completed in eight patients. The reason for this is not reported nor are the methods of participant selection introducing the risk of selection bias. However, upon clinical neurological examination no statistically significant changes were detected between the C-peptide and placebo treatment groups in relation to sensory nerve function, SCV and MCV. The numerical data regarding the outcomes for sensory nerve function in study three can be found in table 3 . The data is presented individually for each of the eight patients and is expressed as the percentage change from baseline (Table 3).

Upon quality and risk of bias assessment a number of limitations were identified with regard to Johansson et al. 1996 study. No further/ in depth detail was given regarding the double-blind and randomised design. The risk of selection, performance and attrition bias cannot be made as it is unknown if the processes of randomisation, allocation and blinding were effectively completed.

\begin{tabular}{|l|c|c|c|c|}
\hline & \multicolumn{2}{|c|}{ AER $(\boldsymbol{\mu g} / \mathbf{m i n})$} & \multicolumn{2}{c|}{ GFR $\left(\mathbf{m l} \cdot \mathbf{m i n}^{-1} \cdot \mathbf{1 . 7 3} \mathbf{~ m}^{-2}\right)$} \\
\hline Period & Group 1 & Group 2 & Group 1 & Group 2 \\
\hline Baseline & 56 & 49 & $106 \pm 6$ & $111 \pm 3$ \\
\hline & C-peptide & Placebo & C-peptide & Placebo \\
\hline 1 months & 46 & 49 & - & - \\
\hline 2 months & 47 & 53 & - & - \\
\hline 3 months & 37 & 69 & $105 \pm 5$ & $111 \pm 5$ \\
\hline & Placebo & C-peptide & Placebo & C-peptide \\
\hline 4 months & 46 & 54 & - & - \\
\hline 5 months & 46 & 36 & - & - \\
\hline 6 months & 51 & 32 & $101 \pm 6$ & $108 \pm 3$ \\
\hline
\end{tabular}

Table 2: AER and GFR at baseline and during months 1-6 in Study 4 (Johansson et al. 2000).

\begin{tabular}{|c|c|c|c|c|c|c|}
\hline \multirow{2}{*}{ Patient ID } & \multicolumn{2}{|c|}{$\begin{array}{c}\text { Vibratory } \\
\text { threshold }\end{array}$} & \multicolumn{2}{c|}{ Heat pain threshold } & \multicolumn{2}{|c|}{$\begin{array}{c}\text { Warm-cold difference } \\
\text { limen }\end{array}$} \\
\cline { 2 - 7 } & C-peptide & Saline & C-peptide & Saline & C-peptide & Saline \\
\hline 1 & -8 & 6 & 1 & 0 & -12 & -5 \\
\hline 2 & 23 & -3 & $\begin{array}{c}\text { Lack of heat pain } \\
\text { prior to treatment }\end{array}$ & 3 & -2 \\
\hline 3 & -2 & 0 & -2 & -1 & 20 & -1 \\
\hline 4 & 2 & 9 & 3 & 0 & 21 & -2 \\
\hline 5 & 10 & -23 & 1 & -3 & 6 & -13 \\
\hline 6 & -19 & 27 & 0 & 1 & -6 & 21 \\
\hline 7 & -46 & -46 & 2 & -2 & 38 & -10 \\
\hline 8 & 59 & -2 & 2 & 3 & 1 & -4 \\
\hline Mean \pm & $2 \pm 11$ & $-4 \pm 8$ & $1 \pm 1$ & $0 \pm 1$ & $9 \pm 6$ & $-2 \pm 4$ \\
\hline SEM & $2 \pm$ & & & & & \\
\hline
\end{tabular}

Table 3: Sensory nerve function outcomes for Study 3 (Johansson et al. 1996).
It is reported that the twelve participants were studied on two different occasions within two to four weeks suggesting a cross-over design although this is not explicitly stated. Due to lack of information, the reviewer is unable to clarify the exact length of time between each study arm although it is recognised that the wash-out period will have been at least two weeks. There is no reported evidence of evaluation of the possible influence of sequence or carry-over effects on the study findings further questioning the validity of the study. Additionally, no power calculation was carried out to determine that the sample size was big enough to minimise the play of chance. The sample size was small with only twelve patients and the C-peptide intervention was only given over a three hour period. More prolonged trials would be necessary to provide more robust findings.

Johansson et al., 2000 (Study 4) also investigated outcomes concerned with sensory and autonomic nerve function. This study provided evidence that suggests C-peptide therapy could ameliorate the autonomic and sensory nerve dysfunction seen in patients with T1DM. Prior to the study, twelve participants demonstrated reduced HRV during deep breathing and therefore had clinical signs of autonomic neuropathy. In these twelve patients HRV increased with C-peptide treatment $(18 \pm 2 \%$ at baseline and $21 \pm 1 \%$ after three months C-peptide administration). In contrast, the HRV during placebo treatment decreased from $19 \pm 1 \%$ at baseline to $16 \pm 1 \%$. The difference seen between the C-peptide and placebo treated groups was significant $(\mathrm{P}<0.025)$. No difference was detected between the groups who received C-peptide during the first treatment period with those who received it during the second period thus ruling out a sequence effect. The remaining nine patients who demonstrated normal HRV at baseline showed no statistically significant changes during the intervention (37 $\pm 3 \%$ at baseline, $36 \pm 3 \%$ after 3 months C-peptide) or control period ( $36 \pm 3 \%$ at baseline, $37 \pm 2 \%$ after 3 months placebo).

Six participants had abnormally low brake indices following tilting at baseline. However, during C-peptide therapy this tended to improve ( $8 \pm 2 \%$ at baseline, $10 \pm 3 \%$ after C-peptide treatment). In two patients acceleration indices were found to be abnormal at $10 \%$ (normal limit $>15 \%$ ). After C-peptide treatment the acceleration index improved in one of the two patients. Both the brake and acceleration indices remained unchanged during the placebo treatment period. It was also found that C-peptide treatment for three months improved the postural hypotension induced by 2-3 minutes of tilting seen in two patients prior to the study. After the intervention period, both participants were able to tolerate the full 8 minutes of tilting with a stable blood pressure. In contrast, after three months placebo treatment they once again suffered from postural hypotension.

In addition, six patients had clinical signs of sensory neuropathy at baseline. A reduction in the thermal threshold value for all tested sites was found when C-peptide was given for three months $\left(17.4 \pm 2.2^{\circ} \mathrm{C}\right.$ at baseline, $13.7 \pm 1.5^{\circ} \mathrm{C}$ during C-peptide administration), however this change was not significant. No change was observed during the placebo period. The average heat pain and VPT showed no significant changes during the two treatment periods. In two patients the disappearance of thermal hypesthesia, thermal allodynia and paradoxical temperature perception was observed during the C-peptide study period. However, these symptoms reappeared during the placebo treatment period.

In 2003, Ekberg et al. (Study 5) found that C-peptide treatment for three months ameliorated nerve dysfunction in patients with T1DM and early signs of diabetic neuropathy [13], which supports work carried out by Kamiya [27]. The NCV in the sural and peroneal nerve (SCV and MCV, respectively) in the diabetic subjects was found to be reduced at baseline when compared with healthy control subjects. 
However, there was no significant difference in the NCV's of the two treatment groups at baseline. A $5 \%$ increase in SCV $(2.7 \pm 0.85 \mathrm{~m} / \mathrm{s}$ change from baseline $\mathrm{P}<0.01$ ) was found in the sural nerve after twelve weeks of C-peptide therapy. In contrast, no statistically significant changes in SCV were found in the placebo treated group. The difference in response between the groups was found to be statistically significant $(\mathrm{P}<0.05)$. A small improvement in MCV $(0.8 \pm 0.32 \mathrm{~m} / \mathrm{s})$ was found after 6 weeks of $\mathrm{C}$-peptide treatment but this improvement was not still apparent at the end of three months. Furthermore, the change was not statistically different from the placebo group.

No significant changes in temperature perceptions were found in either treatment group. However, the VPT over the first metatarsal for the C-peptide treated group showed a significant decrease from 0.63 \pm 0.07 to $0.48 \pm 0.05(\mathrm{P}<0.05)$ arbitrary units after twelve weeks of treatment. This change was statistically significant when compared with placebo $(\mathrm{P}<0.05)$ and is consistent in an improvement in sural nerve function.

Study 6 (Ekberg et al., 2007) found that six months treatment with C-peptide improved the sensory nerve function of T1DM patients with early stage diabetic neuropathy $[14,28]$. The SCV and MCV were found to be significantly reduced at baseline compared with healthy controls. However, all three treatment groups were comparable at baseline. The results from the high-dose and low-dose C-peptide groups were combined for analysis due to the fact that no significant difference was found between the groups. There was a significant improvement in $\operatorname{SCVp}(0.48 \pm 0.19 \mathrm{~m} / \mathrm{s}, \mathrm{P}<0.007)$ and SCVi $(0.93 \pm 0.29 \mathrm{~m} / \mathrm{s}, \mathrm{P}<0.001)$ from baseline in the active treatment group. However, these changes were not significantly different from the placebo group. The number of responders (patients who showed an improvement in SCV of more than $1 \mathrm{~m} / \mathrm{s}$ ) was significantly greater in the group receiving C-peptide than the group receiving placebo $(37 \%$ and $19 \%$ respectively, $\mathrm{P}<0.032)$.

A subgroup analysis was performed due to the fact that it was anticipated that those least affected at baseline might have the greater potential for improvement with regard to SCV. The subgroup consisted of the half of the participants who showed the least affected basal SCV measurements. The results showed that at 6 months of C-peptide therapy the improvement seen in SCVp in the C-peptide group was 0.61 $\pm 0.25 \mathrm{~m} / \mathrm{s}$ compared with a SCVp of $-0.42 \pm 0.29 \mathrm{~m} / \mathrm{s}$ in the placebo treated group. Therefore, the improvement seen in the SCVp for the C-peptide treated group was $1.03 \mathrm{~m} / \mathrm{s}$ greater than that of the placebo group $(\mathrm{P}<0.014)$. The improvement in the $\mathrm{SCVi}$ was even greater at 1.27 $\pm 0.36(\mathrm{P}<0.001)$. Upon further analysis of this subgroup, it was found that the percentage number of responders in the C-peptide treated group was $39 \%$ compared with just $5 \%$ in the placebo group $(\mathrm{P}<0.004)$. No improvements in MCV were found throughout this study and a reduction was seen in all of the treatment groups.

Within the C-peptide treated groups, a significant improvement was found in VPT $(\mathrm{P}<0.01)$. No significant changes were found in the placebo group for the same outcome. Furthermore, no significant changes were found in any of the treatment groups with regard to temperature perception.

\section{Meta-Analysis}

The meta-analysis carried out examined GFR, Albumin Excretion, $\mathrm{MCV}, \mathrm{SCV}$, vibratory thresholds, thermal thresholds and Heart rate variability as outcomes.

Three studies were examined to compare the effects of C-peptide versus placebo. The results for each outcome comparing C-peptide and placebo are presented in forest plots below. C-peptide was also found to exert a beneficial effect upon GFR (Figure 2a and 2b), SCV (Figure $3 \mathrm{a}$ and $3 \mathrm{~b}$ ) and VPT (Figure $4 \mathrm{a}$ and $4 \mathrm{~b}$ ); however, the effects were not statistically significant $(\mathrm{P}=0.07, \mathrm{P}=0.20$ and $\mathrm{P}=0.22$ respectively).

C-peptide was found to exert a statistically significant beneficial effect upon urinary albumin excretion $(\mathrm{P}=0.0006)$ (Figure 2a) and HRV $(\mathrm{P}=0.01)$ (Figure 5) when the results of the included primary studies were statistically combined.

The data from primary studies investigating GFR had wide confidence intervals, indicating that the findings have poor precision. C-peptide was not found to exert an effect upon MCV (Figure 3a). The response of thermal thresholds (Figure $4 \mathrm{~b}$ ) to $\mathrm{C}$-peptide varied greatly in the included studies. Subsequently, C-peptide was not found to exert statistically significant changes to this outcome upon analysis.

As a result, more in depth investigation is required.

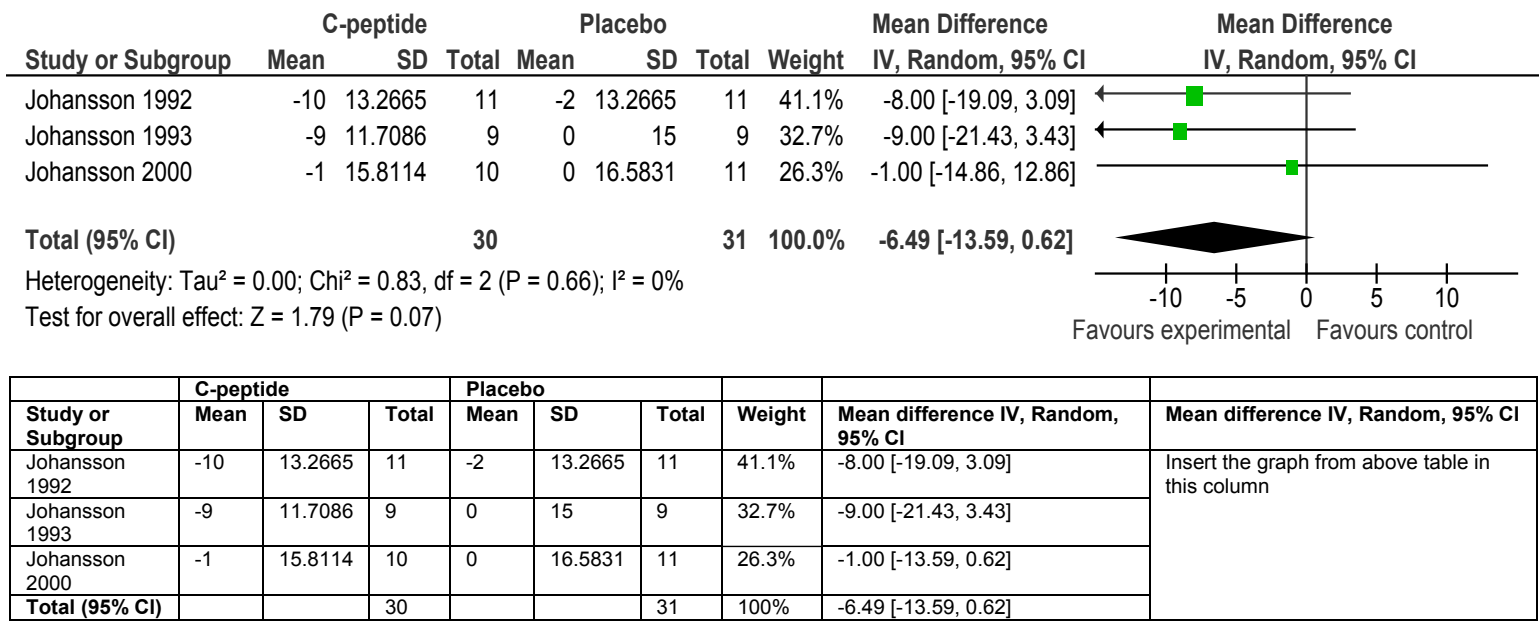

Heterogeneity: $\mathrm{Tau}^{2}=0.00 ; \mathrm{Chi}^{2}=0.83 ; \mathrm{df}=2(\mathrm{P}=0.66) ; \mathrm{l}^{2}=0 \%$

Test for overall effect: $Z=1.79(P=0.007)$

Figure 2a: Comparison: C-peptide vs. Placebo, Outcome: GFR 
Citation: Adams G, Champion S, Figg G, Jervis A (2013) The Therapeutic Role of C-peptide in the Amelioration of Type 1 Diabetes Associated Microvascular Dysfunction of the Kidneys and Nerves. J Diabetes Metab 4: 267. doi:10.4172/2155-6156.1000267

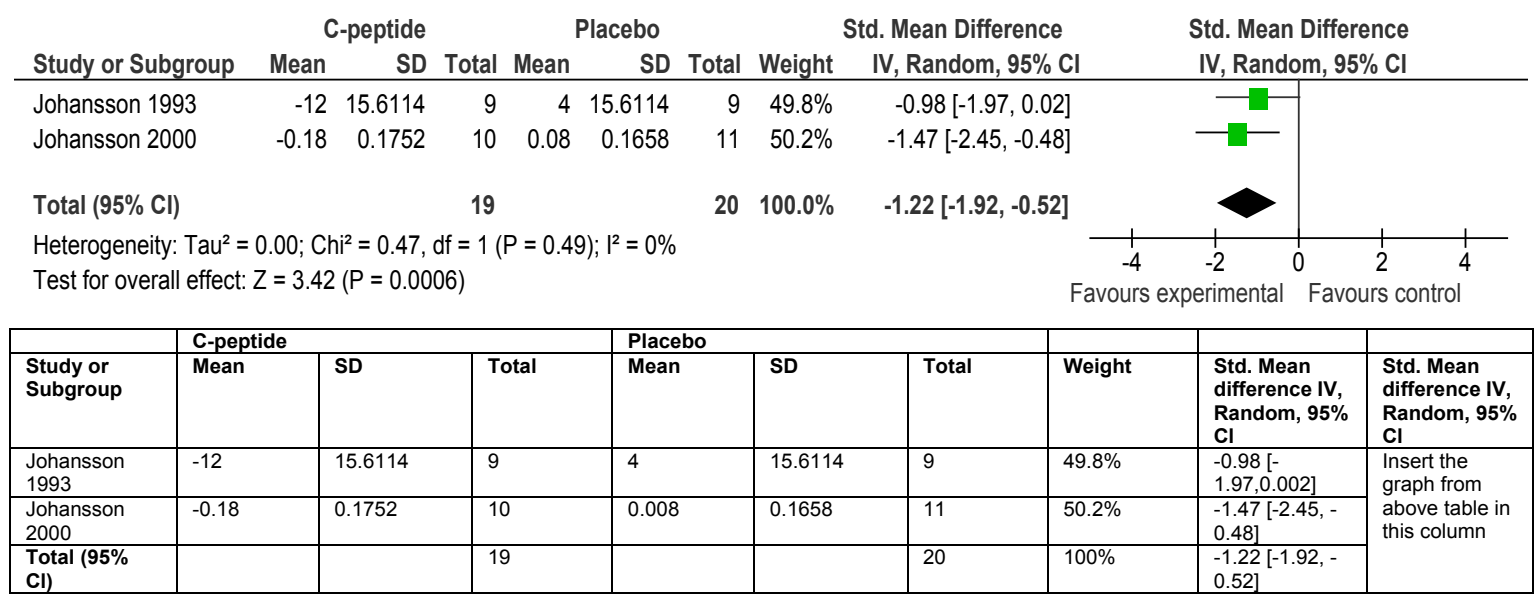

Heterogeneity: $\mathrm{Tau}^{2}=0.00 ; \mathrm{Chi}^{2}=0.47 ; \mathrm{df}=1(\mathrm{P}=0.49) ; \mathrm{l}^{2}=0 \%$

Test for overall effect: $Z=3.42(P=0.0006)$

Figure 2b: Comparison: C-peptide vs. Placebo, Outcome: Albumin Excretion.

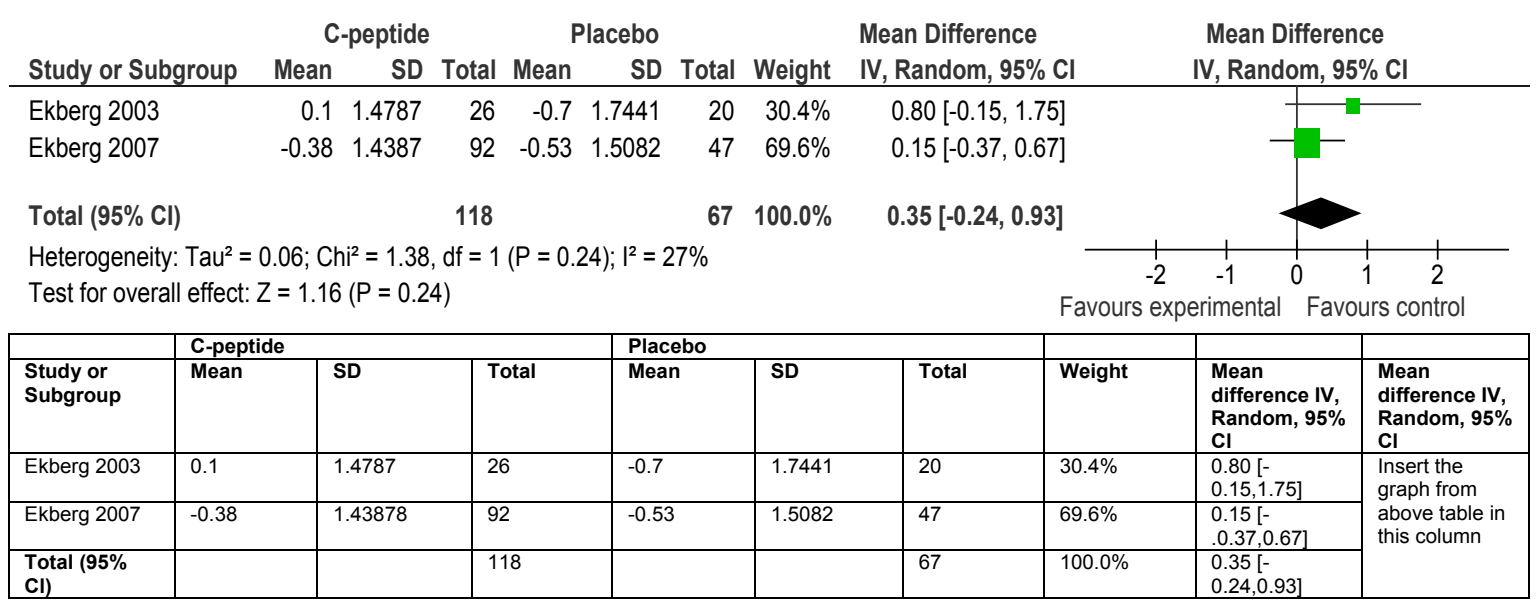

Heterogeneity: Tau $^{2}=0.06 ; \mathrm{Chi}^{2}=1.38 ; \mathrm{df}=1(\mathrm{P}=0.24) ; \mathrm{l}^{2}=27 \%$

Test for overall effect: $Z=1.16(P=0.24)$

Figure 3a: Comparison: C-peptide vs. Placebo, Outcome: MCV.

\section{Conclusion}

C-peptide replacement may have a significant impact in the prevention and treatment of microvascular complications associated with T1DM. C-peptide exerts beneficial effects upon outcomes of kidney and nerve function in humans with T1DM. In terms of the importance of C-peptide effect on urinary albumin excretion, the development of diabetic nephropathy is associated with structural changes which have a detrimental impact upon the function of the kidneys. Albumin presence in the urine is a marker of such changes. Since evidence suggests that C-peptide has the ability to reduce urinary albumin excretion, it can be argued that C-peptide may protect the kidneys from T1DM-induced structural changes thus preserving renal function.

Glomerular hyperfiltration is a phenomenon observed early in T1DM and is linked to the future development of diabetic nephropathy. C-peptide was found to reduce GFR during preclinical stages of diabetic nephropathy. C-peptide therapy given early in the course of
T1DM, may ameliorate the microvascular dysfunction associated with the kidneys and exert a renoprotective role.

Where patients are C-peptide deficient, diabetic neuropathy in T1DM is associated with more pronounced structural and functional changes to the nerves than T2DM. C-peptide administration resulted in improvements in measures of sensory nerve function, through modulation of eNOS and $\mathrm{Na}^{+} \mathrm{K}^{+}$-ATPase activities and has a beneficial impact upon the structure and therefore the function of peripheral nerves. C-peptide has the potential to reduce the severity and detrimental impact of the nerve dysfunction experienced by patients with T1DM.

C-peptide has also been found to improve cardiac autonomic neuropathy as evidenced by improvements in HRV. Since autonomic neuropathy is known to lead to a number of debilitating complications and increased risk of cardiovascular mortality, it is postulated that C-peptide may play an important role in ameliorating the progression of this complication and could therefore be beneficial treatment adjunct for patients with T1DM. 
Citation: Adams G, Champion S, Figg G, Jervis A (2013) The Therapeutic Role of C-peptide in the Amelioration of Type 1 Diabetes Associated Microvascular Dysfunction of the Kidneys and Nerves. J Diabetes Metab 4: 267. doi:10.4172/2155-6156.1000267

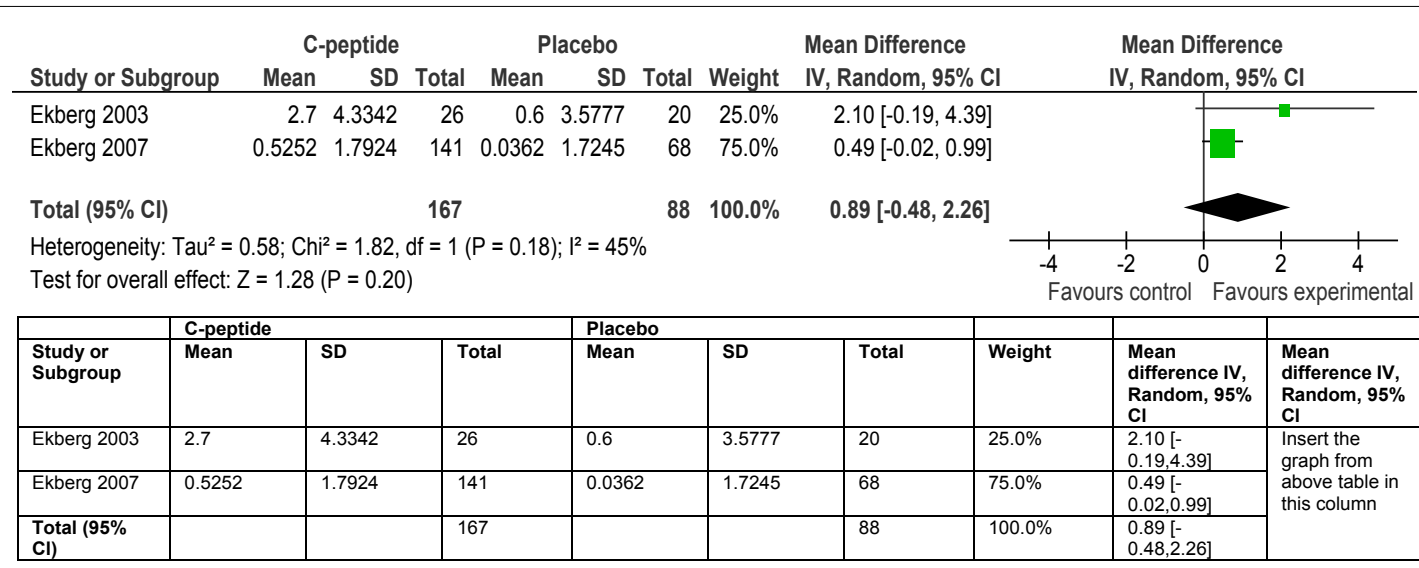

Heterogeneity: $\mathrm{Tau}^{2}=0.58 ; \mathrm{Chi}^{2}=1.82 ; \mathrm{df}=1(\mathrm{P}=0.18) ; \mathrm{I}^{2}=45 \%$

Test for overall effect: $Z=1.28(P=0.20)$

Figure 3b: Comparison: C-peptide vs. Placebo, Outcome: MSCVa

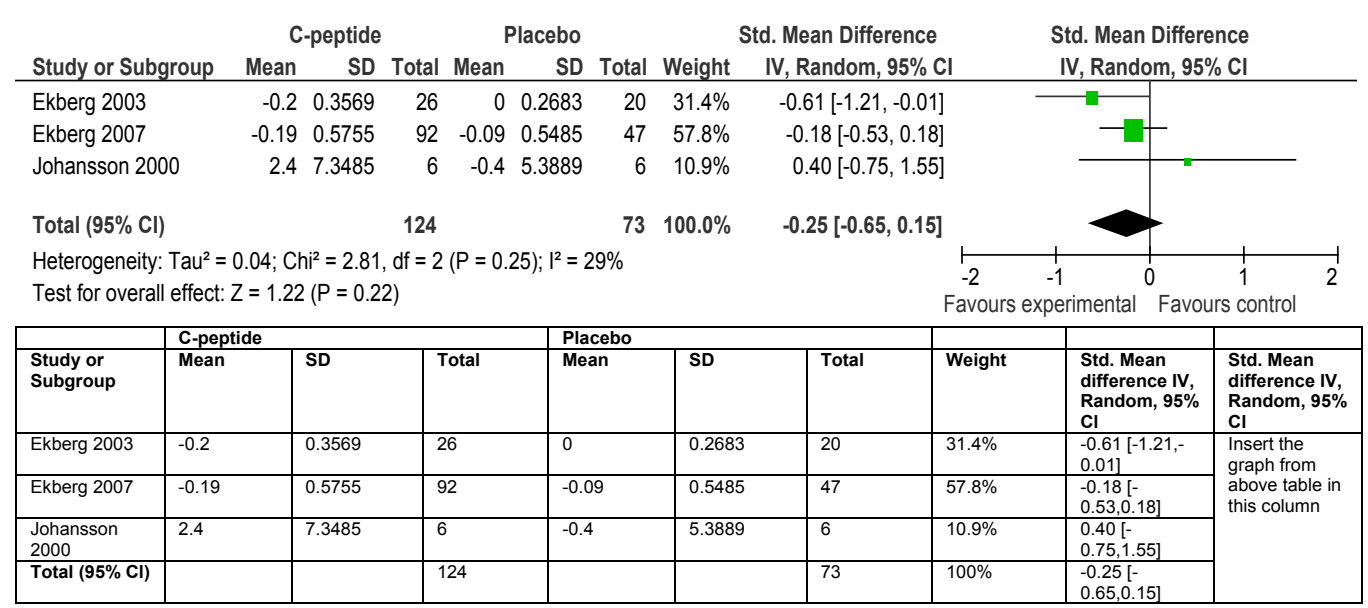

Heterogeneity: Tau $^{2}=0.04 ; \mathrm{Chi}^{2}=2.81 ; \mathrm{df}=2(\mathrm{P}=0.25) ; \mathrm{l}^{2}=29 \%$

Test for overall effect: $Z=1.22(P=0.22)$

Figure 4a: Comparison: C-peptide vs. Placebo, Outcome: Vibratory Threshold.

\begin{tabular}{|c|c|c|c|c|c|c|c|c|c|c|c|c|}
\hline \multirow{2}{*}{\multicolumn{2}{|c|}{ Study or Subgroup }} & \multicolumn{3}{|c|}{ C-peptide } & \multicolumn{3}{|c|}{ Placebo } & \multicolumn{3}{|c|}{ Std. Mean Difference } & \multirow{2}{*}{\multicolumn{2}{|c|}{$\begin{array}{l}\text { Std. Mean Difference } \\
\text { IV, Random, } 95 \% \mathrm{CI}\end{array}$}} \\
\hline & & Mean & SD & Total & Mean & SD & Total & Weight & IV, Random, $95 \% \mathrm{Cl}$ & & & \\
\hline \multicolumn{2}{|c|}{ Ekberg 2003} & 0.3 & 1.5807 & 26 & 0.1 & 1.1628 & 20 & $41.3 \%$ & $0.14[-0.44,0.72]$ & & - & \\
\hline \multicolumn{2}{|c|}{ Johansson 1996} & 9 & 16.9706 & 8 & -2 & 11.3137 & 8 & $32.6 \%$ & $0.72[-0.30,1.74]$ & & & \\
\hline \multicolumn{2}{|c|}{ Johansson 2000} & -3.7 & 3.5257 & 6 & 0.9 & 1.6 & 6 & $26.2 \%$ & $-1.55[-2.91,-0.19]$ & & & \\
\hline \multicolumn{2}{|l|}{ Total $(95 \% \mathrm{Cl})$} & \multicolumn{3}{|c|}{40} & & & 34 & $100.0 \%$ & $-0.11[-1.15,0.93]$ & & & \\
\hline \multicolumn{10}{|c|}{$\begin{array}{l}\text { Heterogeneity: } \text { Tau }^{2}=0.59 ; \mathrm{Chi}^{2}=7.06, \mathrm{df}=2(P=0.03) ; \mathrm{I}^{2}=72 \% \\
\text { Test for overall effect: } Z=0.21(P=0.83)\end{array}$} & \multicolumn{3}{|c|}{ 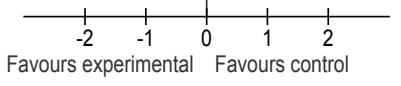 } \\
\hline $\begin{array}{l}\text { Study or } \\
\text { Subgroup }\end{array}$ & $\begin{array}{l}\text { C-pe } \\
\text { Mear }\end{array}$ & & SD & & Total & \multicolumn{2}{|c|}{$\begin{array}{l}\text { Placebo } \\
\text { Mean }\end{array}$} & SD & Total & Weight & $\begin{array}{l}\text { Std. Mean } \\
\text { difference IV, } \\
\text { Random, } 95 \% \\
\text { Cl }\end{array}$ & $\begin{array}{l}\text { Std. Mean } \\
\text { difference IV, } \\
\text { Random, } 95 \% \\
\text { Cl }\end{array}$ \\
\hline Ekberg 2003 & 0.3 & & 1.5807 & & 26 & 0.1 & & 1.1628 & 20 & $41.3 \%$ & $\begin{array}{l}0.14[- \\
0.44,0.72] \\
\end{array}$ & $\begin{array}{l}\text { Insert the } \\
\text { graph from }\end{array}$ \\
\hline $\begin{array}{l}\text { Johansson } \\
1996 \\
\end{array}$ & 9 & & 16.9706 & $\varepsilon$ & & -2 & & 11.3137 & 8 & $32.6 \%$ & $\begin{array}{l}0.72[- \\
0.30,1.74] \\
\end{array}$ & $\begin{array}{l}\text { above table in } \\
\text { this column }\end{array}$ \\
\hline $\begin{array}{l}\text { Johansson } \\
2000\end{array}$ & -3.7 & & 3.5257 & 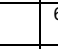 & & 0.9 & & 1.6 & 6 & $26.2 \%$ & $\begin{array}{l}-1.55[-2.91,- \\
0.19]\end{array}$ & \\
\hline $\begin{array}{l}\text { Total }(95 \% \\
\text { Cl) }\end{array}$ & & & & & 40 & & & & 34 & $100 \%$ & $\begin{array}{l}-0.11[- \\
1.15,0.93]\end{array}$ & \\
\hline
\end{tabular}

Heterogeneity: Tau $^{2}=0.59 ; \mathrm{Chi}^{2}=7.06 ; \mathrm{df}=2(\mathrm{P}=0.03) ; \mathrm{l}^{2}=72 \%$

Test for overall effect: $Z=0.21(P=0.83)$

Figure 4b: Comparison: C-peptide vs. Placebo, Outcome: Thermal Threshold. 
Citation: Adams G, Champion S, Figg G, Jervis A (2013) The Therapeutic Role of C-peptide in the Amelioration of Type 1 Diabetes Associated Microvascular Dysfunction of the Kidneys and Nerves. J Diabetes Metab 4: 267. doi:10.4172/2155-6156.1000267

Page 10 of 10

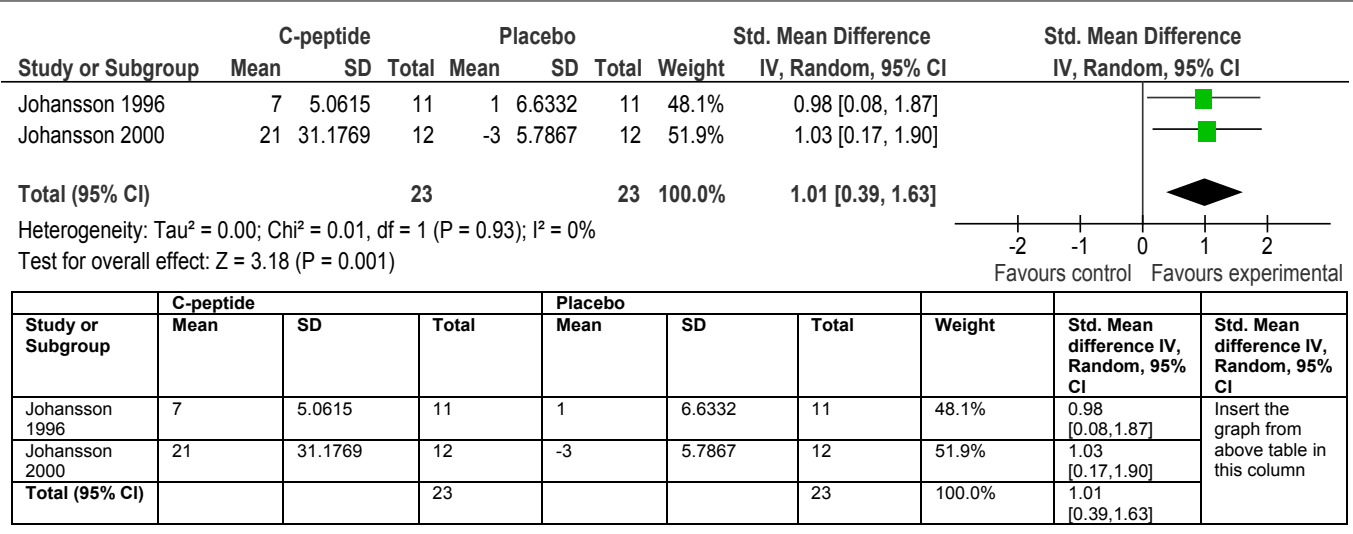

Heterogeneity: $\mathrm{Tau}^{2}=0.00 ; \mathrm{Chi}^{2}=0.01 ; \mathrm{df}=1(\mathrm{P}=0.93) ; \mathrm{I}^{2}=0 \%$

Test for overall effect: $Z=3.18(P=0.001)$

Figure 5: Comparison: C-peptide vs. Placebo, Outcome: Heart Rate Variability.

\section{Author Contributions}

SC/GF/AJ/GA: researched data wrote manuscript, reviewed/edited manuscript/contributed to discussion.

\section{Acknowledgements}

\section{Guarantor's Statement}

Dr. Adams is the guarantor of this work and, as such, had full access to all the data in the study and takes responsibility for the integrity of the data and the accuracy of the data analysis.

\section{References}

1. Preis SR, Pencina MJ, Mann DM, D'Agostino RB Sr, Savage PJ, et al. (2013) Early-adulthood cardiovascular disease risk factor profiles among individuals with and without diabetes in the framingham heart study. Diabetes Care 36 : 1590-1596.

2. George PS, Pearson ER, Witham MD (2012) Effect of vitamin D supplementation on glycaemic control and insulin resistance: a systematic review and metaanalysis. Diabet Med 29: e142-150.

3. Daneman D (2006) Type 1 diabetes. Lancet 367: 847-858.

4. Wang S, Wei W, Zheng Y, Hou J, Dou Y, et al. (2012) The role of insulin $\mathrm{C}$-peptide in the coevolution analyses of the insulin signaling pathway: a hint for its functions. PLoS One 7: e52847.

5. Hills CE, Brunskill NJ, Squires PE (2010) C-peptide as a therapeutic tool in diabetic nephropathy. Am J Nephrol 31: 389-397.

6. Uchizono Y, Alarcón C, Wicksteed BL, Marsh BJ, Rhodes CJ (2007) The balance between proinsulin biosynthesis and insulin secretion: where can imbalance lead? Diabetes Obes Metab 9 Suppl 2: 56-66.

7. Rubenstein AH, Clark JL, Melani F, Steiner DF (1969) Secretion of Proinsulin C-Peptide by Pancreatic $B$ Cells and its Circulation in Blood. Nature 224: 697-699.

8. Wahren J, Jörnvall H (2003) C-peptide makes a comeback. Diabetes Metab Res Rev 19: 345-347.

9. Wahren J, Shafqat J, Johansson J, Chibalin A, Ekberg K, et al. (2004) Molecular and cellular effects of C-peptide--new perspectives on an old peptide. Exp Diabesity Res 5: 15-23.

10. Samnegård B, Jacobson SH, Jaremko G, Johansson BL, Sjöquist M (2001) Effects of C-peptide on glomerular and renal size and renal function in diabetic rats. Kidney Int 60: 1258-1265.

11. Rebsomen L, Pitel S, Boubred F, Buffat C, Feuerstein JM, et al. (2006) C-peptide replacement improves weight gain and renal function in diabetic rats. Diabetes Metab 32: 223-228.

12. Johansson BL, Borg K, Fernqvist-Forbes E, Kernell A, Odergren T, et al. (2000) Beneficial effects of C-peptide on incipient nephropathy and neuropathy in patients with Type 1 diabetes mellitus. Diabet Med 17: 181-189.
13. Ekberg K, Brismar T, Johansson BL, Jonsson B, Lindström $P$, et al. (2003) Amelioration of sensory nerve dysfunction by C-Peptide in patients with type 1 diabetes. Diabetes 52: 536-541.

14. Ekberg K, Brismar T, Johansson BL, Lindström P, Juntti-Berggren L, et al. (2007) C-Peptide replacement therapy and sensory nerve function in type 1 diabetic neuropathy. Diabetes Care 30: 71-76.

15. Johansson BL, Sjöberg S, Wahren J (1992) The influence of human C-peptide on renal function and glucose utilization in type 1 (insulin-dependent) diabetic patients. Diabetologia 35: 121-128.

16. Sawyer RT, Flynn ER, Hutchens ZM Jr, Williams JM, Garrett MR, et al. (2012) Renoprotective effects of C-peptide in the Dahl salt-sensitive rat. Am J Physio Renal Physiol 303: F893-899.

17. Chima RS, Maltese G, Lamontagne T, Piraino G, Denenberg A, et al. (2011) C-peptide ameliorates kidney injury following hemorrhagic shock. Shock 35 524-529.

18. Machin, D, Day S, Green S (2006) Textbook of Clinical Trials. ( $2^{\text {nd }}$ edn) Chichester: John Wiley and Sons Ltd.

19. Nordquist L, Brown R, Fasching A, Persson P, Palm F (2009) Proinsulin C-peptide reduces diabetes-induced glomerular hyperfiltration via efferent arteriole dilation and inhibition of tubular sodium reabsorption. Am J Physio Renal Physiol 297: F1265-F1272. .

20. Nordquist L, Palm F, Andresen BT (2008) Renal and vascular benefits of C-peptide: Molecular mechanisms of C-peptide action. Biologics 2: 441-452.

21. Nordquist L, Wahren J (2009) C-Peptide: the missing link in diabetic nephropathy? Rev Diabet Stud 6: 203-210.

22. Johansson BL, Kernell A, Sjöberg S, Wahren J (1993) Influence of combined C-peptide and insulin administration on renal function and metabolic control in diabetes type 1. J Clin Endocrinol Metab 77: 976-981.

23. Solomon PL, Cavanaugh MM, Draine J (2009) Randomized Contro Trials: Design and Implementation for Community-Based Psycho-socia Interventions2009, Oxford: Oxford University Press.

24. Salkind, NJ (2008) Statistics for people who (think they) hate statistics London: Sage Publications Ltd.

25. Johansson BL, Borg K, Fernqvist-Forbes E, Odergren T, Remahl S, et al. (1996) C-peptide improves autonomic nerve function in IDDM patients. Diabetologia 39: 687-695.

26. Galuska D, Pirkmajer S, Barrès R, Ekberg K, Wahren J, et al. (2011) C-peptide increases $\mathrm{Na}, \mathrm{K}$-ATPase expression via PKC- and MAP kinase-dependent activation of transcription factor ZEB in human renal tubular cells. PLoS One 6: e28294.

27. Kamiya H, Zhang W, Sima AA (2009) The beneficial effects of C-Peptide on diabetic polyneuropathy. Rev Diabet Stud 6: 187-202.

28. Ekberg K, Johansson BL (2008) Effect of C-peptide on diabetic neuropathy in patients with type 1 diabetes. Exp Diabetes Res 2008: 457912. 